\title{
Serum precipitin reactions in Hashimoto's thyroiditis
}

\author{
J. M. MOORE
}

From the Department of Bacteriology, Stobhill General Hospital, Glasgow

SYNOPSIS Sera from certain patients with Hashimoto's disease or a related condition contain a non-precipitating antithyroglobulin which produces in double-diffusion tests with thyroglobulin a line of clearing in the agar. Two such sera are described.

Other sera from examples of the disease give negative precipitin tests with thyroglobulin but combine with sera containing 'clear line', non-precipitating antithyroglobulin to give a positive precipitin test. The serum from 15 out of 26 precipitin-negative cases of Hashimoto's disease showed this latent property. Eight of the 15 were tested by the tanned red cell technique and showed substantial titres of antithyroglobulin.

The presence of auto-antibodies in Hashimoto's disease was first described in 1956 (Roitt, Doniach, Campbell, and Vaughan-Hudson). Their importance as an aid to the diagnosis of the condition is generally accepted even if their role in producing cell damage is not. The test for precipitating antithyroglobulin is in common use but this antibody cannot be detected in many cases of the disease. The presence of nonprecipitating antithyroglobulin in the serum of certain cases of Hashimoto's disease was described by Goudie, Anderson, and Gray (1959) who found that this antibody produced between serum and thyroglobulin 'wells' on an Ouchterlony plate a line of clearing in the agar's slight milky opacity. This was shown by chemical means to be a zone of high protein concentration. It was also noted by these workers that sera producing this phenomenon had enhancing properties, i.e., when they were allowed to diffuse into the area of agar between a 'well' containing thyroglobulin and a 'well' containing serum from certain precipitin-negative cases of Hashimoto's disease, a precipitate appeared which did not do so in the absence of the enhancing serum.

This clearing phenomenon was observed independently in this laboratory and no doubt in others also. Two patients with such sera have been encountered, and one of these, patient $\mathrm{L}$, has been observed over a period of three years and her thyroid gland examined histologically. The other, patient $\mathbf{M}$, has been observed for a much shorter period. Serum from the latter gave a line of clearing unaccompanied by precipitate. That from patient $L$ has shown a transition over the years through the

Received for publication 14 October 1960. phases (1) line of precipitate only, (2) line of precipitate plus line of clearing, (3) line of clearing only, and (4) no reaction. The sera from these patients will be named $L$ and $M$. Their value as enhancing sera was compared and the effect of combining them was tested.

\section{METHODS}

All precipitin tests were made on Ouchterlony plates at room temperature, using $\mathbf{0 . 7 5} \%$ Difco agar in physiological saline in which $0.03 \%$ sodium azide was incorporated to minimize contamination. The antigen used was a crude saline extract of thyroid gland obtained at operation. The gland was frozen, sliced thinly, and left at $4^{\circ} \mathrm{C}$. for $48 \mathrm{hr}$. in three times its bulk of physiological saline. The supernatant fluid was centrifuged to remove particulate matter and was stored in the frozen state; it was diluted 1 in 4 in saline for use.

Two types of test were used. In the first (Fig. 1) the enhancing serum (in this case $M$ ) was set up alongside four precipitin-negative Hashimoto sera and allowed to diffuse into the area of agar between test sera and antigen. In the second, mixtures of enhancing and test sera in various proportions were set up directly against antigen.

The titre of 'clear line' non-precipitating antithyroglobulin in serum $L$ and serum $M$ was determined approximately by testing doubling dilutions of the serum against antigen, the titre being that dilution still giving a line of clearing.

Tanned red cell tests were made with Burroughs Wellcome reagents using the method recommended by the makers.

\section{RESULTS}

Figure 2 shows that an enhancing serum fails to affect the outcome when a strong precipitin is present in the 


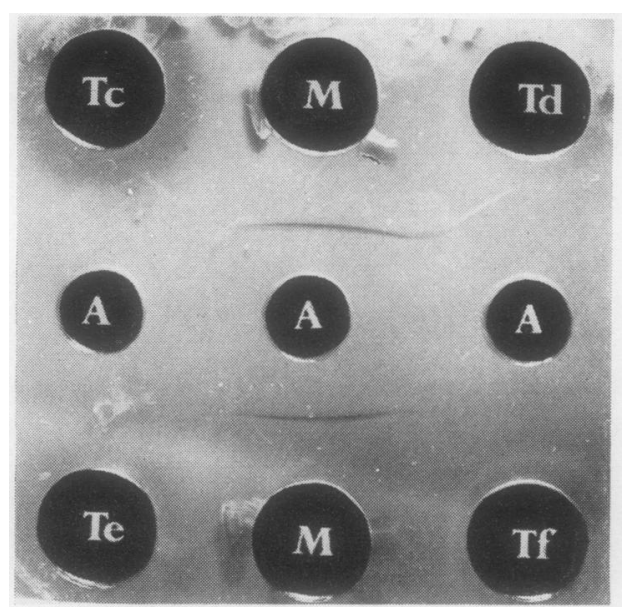

FIG. 1. 'Clear line' serum $M$ used to detect by diffusion the latent precipitating component in precipitin-negative Hashimoto sera. Tc and Td are such sera giving a positive result: Te and $T f$ give a negative result. $A=$ antigen.

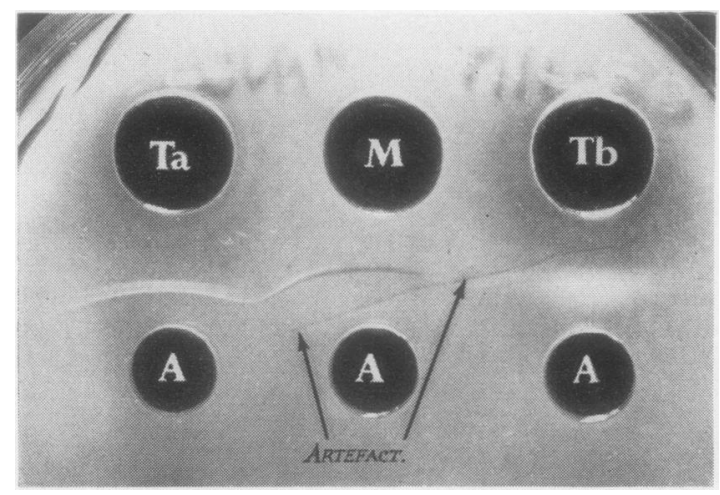

FIG. 2. 'Clear line' serum $M$ reacting alongside serum $\mathrm{Ta}$ and serum $\mathrm{Tb}$, both of which contain strong precipitin. $A=$ antigen.

test Hashimoto serum. The enhancing serum, however, does interact with certain precipitin-negative Hashimoto sera as already shown, and Table I summarizes the results of combining these by diffusion or direct mixture. The sera tested included all cases diagnosed as examples of Hashimoto's disease by physicians of this hospital's endocrine clinic. Many of these patients had been receiving treatment for the condition for a considerable time before the tests described were made.

Group 2 is the one of most interest. Sera from 15
TABLE I

RESULTS OF PRECIPITIN TESTS IN PATIENTS WITH HASHIMOTO'S DISEASE

\begin{tabular}{|c|c|c|c|c|}
\hline \multirow[b]{2}{*}{ Group } & \multicolumn{3}{|c|}{ WITH HASHIMOTO'S DISEASE } & \multirow{2}{*}{$\begin{array}{l}\text { Total in } \\
\text { Group }\end{array}$} \\
\hline & $\begin{array}{l}\text { Number of } \\
\text { Cases }\end{array}$ & $\begin{array}{l}\text { Test for } \\
\text { Precipitin }\end{array}$ & $\begin{array}{l}\text { Test for } \\
\text { Enhancement }\end{array}$ & \\
\hline \multirow{6}{*}{1} & 7 & +++ & - & \\
\hline & 5 & +++ & Not tested & \\
\hline & 2 & + & - & $20(39 \%)$ \\
\hline & 3 & + & & \\
\hline & 1 & & Not tested & \\
\hline & 2 & Clear band & & \\
\hline \multirow{3}{*}{2} & 15 & - & $\div$ & \\
\hline & 11 & - & - & $31(61 \%)$ \\
\hline & 5 & - & Not tested & \\
\hline
\end{tabular}

precipitin-negative cases out of a total of 26 tested were found to be enhanced. Sera $L$ and $M$ had no such effect on precipitin-negative sera from $88^{\circ}$ 글 patients without thyroid disease and from 33 with $\vec{\oplus}$ thyroid disease not of auto-immune type. Histo- $\mathbb{D}$ logical examination had shown the presence of $\frac{\mathbb{D}}{\mathbb{D}}$ Hashimoto's thyroiditis in several of the 15 patients whose sera were enhanced.

The very strong enhancing effect of serum $L$ and $\vec{\theta}$ serum $M$ on one another is shown in Fig. 3. Theiro

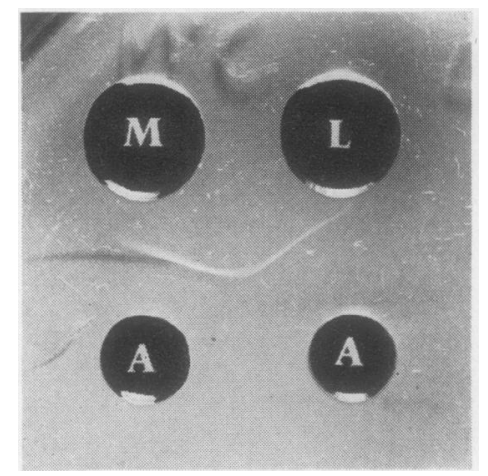

FIG. 3. 'Clear line' $L$ and $M$ sera set up alongside one another. $A=$ antigen.

'line of clearing' titres, determined by dilution as described above, were $1 / 16(\mathrm{~L})$ and $1 / 3(\mathrm{M})$. Taking this difference into account, mixtures of $L$ and $M^{\omega}$ with Group 2 sera capable of enhancement did not give identical results when tested for precipitin, and this perhaps indicates a qualitative difference in the two (Table II).

Serum $L$ and serum $M$ both gave titres of $1 / 25,000{ }^{\circ}$ with the tanned red cell test, and eight of the sera from group 2 capable of enhancement which were? tested gave titres ranging from $1 / 2,500$ to $1 / 25,000$. 
TABLE II

COMPARISON OF ENHANCING EFFECTS OF SERA L AND $M$ IN MIXTURES WITH PRECIPITIN-NEGATIVE HASHIMOTO SERA

\begin{tabular}{ccc} 
Test Serum & Serum $\boldsymbol{M}$ & Serum $L$ \\
\hline 1 & - & + \\
2 & + & + \\
3 & - & + \\
4 & - & + \\
5 & + & +
\end{tabular}

\section{CASE REPORTS}

Patients $L$ and $M$ were a little unusual clinically as well as serologically.

$M$ had splenomegaly and evidence of mild hypersplenism at the times serum was obtained. The reason for this was not elucidated.

$\mathrm{L}$ was considered to be a fairly typical case of Hashimoto's disease until the onset of rapid, painful, diffuse enlargement of the thyroid gland. Malignancy was suspected and substantial portions of each lobe were excised. The histological picture was reported by Dr. H. McD. Cameron to be that of struma reticulosa (Brewer and Orr, 1953). The serum component causing a line of clearing in agar was detected one year before the gland enlarged and persisted for six months after partial thyroidectomy.

\section{DISCUSSION}

The eight precipitin-negative sera tested for antithyroglobulin and capable of enhancement all showed substantial tanned red cell titres. Other sera with similar titres gave a positive precipitin reaction. Thus the negative precipitin test in certain cases of Hashimoto's disease is not explained by too low a serum level of antithyroglobulin.
It seems that sera from cases of Hashimoto's disease may react in gel precipitin tests positively to give a line of precipitate and/or a line of clearing in unclear agar, or negatively, to show no detectable change. Mixtures of sera reacting negatively also react negatively but when such sera are mixed with those capable of producing a line of clearing in agar the mixture in a majority of cases reacts positively in precipitin tests, a line of precipitation being obtained if optimum proportions of the constituents are chosen.

Such differences in antibody behaviour are usually ascribed to differences in avidity for antigen at different stages of an immune process. Slight chemical or physical differences in antibody or the presence or absence of complementary or inhibitory substances might explain 'differences in avidity'. From the less theoretical point of view it can be said that a precipitin-negative Hashimoto serum is serologically very similar to a precipitin-positive one, since in most cases it has a latent capacity to take part in a precipitin reaction with thyroglobulin.

I am grateful to Drs. T. J. Thomson, W. D. Smith, Campbell Love, and M. McNicol for the opportunity to examine sera from their patients and for their cooperation. I am indebted also to Dr. John S. Stevenson for encouragement and advice, to Mr. P. Waldie and his staff for photographs, and to Dr. H. McD. Cameron for permission to summarize his histological report.

\section{REFERENCES}

Brewer, D. B., and Orr, J. W. (1953). J. Path. Bact., 65, 193.

Goudie, R. B., Anderson, J. R., and Gray, K. G. (1959). Immunology, 2, 309.

Roitt, I. M., Doniach, D., Campbell, P. N., and Vaughan-Hudson, R. (1956). Lancet, 2, 820. 